\title{
The Skagen Well
}

\section{The Skagen Well - perspectives}

The perspectives of the drilling of the Skagen Well can be seen by describing the sedimental changes observed in the succession of strata penetrated. However, for the first $30 \mathrm{~m}$ of Skagen Well III, only wash-samples were taken, in order to establish the well for further drilling down to the Prequaternary. Therefore, the first drilling segment, composed of sand and gravel, was later repeated elsewhere in order to obtain core samples also from the topmost part. This was done in a nearby position - the so-called Skagen IV Well - and consequently the full record of shell material and sediments can be given from the core samples obtained from the well, representing all the strata met with in the Skagen area from the Quaternary, the Skagen III Well DGU File No. 1.287.

The Skagen Wells III and IV are considered to represent one well and are therefore listed together. However, also the wash-samples obtained throughout the Quaternary are represented, but only as qualitative analyses with the first occurrences of macrofossils especially the molluscs - indicated (Appendix 2).

Thirty metres below surface (+ $1 \mathrm{~m}$ a.s.), the sediment is well-sorted fine sand. For the following $10 \mathrm{~m}$ to $40 \mathrm{~m}$ b.s., the average grain size falls within the coarse silt fraction which is consistent down to $75 \mathrm{~m}$ b.s. as shown from 11 interjacent measurements, Appendix 3 .

From the depth of $75 \mathrm{~m}$ b.s. the average diameter falls within that of medium silt, down to the level of $100 \mathrm{~m}$ b.s., still well sorted.

At the following levels to a depth of $133 \mathrm{~m}$ b.s., the material is fine silt and clay. At a depth of $135 \mathrm{~m}$ b.s., fine sand with poor sorting occurs, and at 136-137 m b.s., with very poor sorting and quartiles 40\% / 90\% of 54.099, which shows a diamict material with a content of stones and only allochthonous shell material, in contrast to the superjacent $130 \mathrm{~m}$.

At a depth of $179 \mathrm{~m}$, the well produced a fine-grained material of medium silt, moderately sorted, which is close to what was found above the diamict sequence.

With some rise in the average diameter to fine sand and a lowering of the sorting, the next remarkable shift happens at a depth of $187 \mathrm{~m}$ b.s., where a new diamict sequence is found down to $195 \mathrm{~m}$ b.s. Here the boundary to the Prequaternary deposits is met with, most probably belonging to the Lower Cretaceous, according to Skagen II, DGU File No. 1, 43 (Sorgenfrei \& Buch 1964).

From the above-mentioned strata in the cored sections, the well can be divided into two parts from the point of view of the present investigation on macrofossils. A sandy to gravelly, clayey to silty wellsorted material found in the upper $130 \mathrm{~m}$ of the well and in a smaller interval of almost $10 \mathrm{~m}$ at a depth of 179 to $187 \mathrm{~m}$ b.s. Between these two parts, diamict and well-sorted clayey layers without an in situ macrofauna are found.

As the main characteristic feature of the $140 \mathrm{~m}$ finegrained and well-sorted material, its content of shellbearing marine molluscs is considered. However, also other marine macrofossils have been recognised but not referred to species level, although recorded on a higher taxonomic level in Appendix 3, which represents the finds in the Skagen Well.

Also the sedimental data are all shown in Appendix 3, allowing a direct comparison between the finds of faunal elements and lithology sensu lato. The organic compound is shown with loss on ignition $\left(550^{\circ} \mathrm{C}\right)$ and the occurrences of concretions such as pyrite and iron compounds. Also allochthonous shell materials are figured. In consequence of the quantitative analyses of molluscs, diversity and number of specimens are given for the marine strata throughout the whole sequence. It is shown that these figures are very greatly according to the different facies met with.

On the basis of the dating within the limits of the carbon-14 method (Heier-Nielsen et al. 1995), Appendix 4 and Fig. 3, it is seen that the $130 \mathrm{~m}$ thick upper sequence of the well is dated to the last $15000{ }^{14} \mathrm{C}$ years. This comprises the whole of the Holocene with its Boreal sea deposits and the Late Weichselian with the Arctic Younger Yoldia deposits.

But also from 140-150 m b.s., measurements on gas compounds of marine origin (T. Layer, personal communication 1999) and shell fragments have been dated, giving ages around 36000 B.P. ${ }^{14} \mathrm{C}$ years. This means that the diamictic sequence occurring between the two marine strata has taken up material which in age is equivalent to the younger part of the Older Yoldia Clay sediments. The deposition of the diamictic 
sediments is referred to the time of the Late Weichselian ice advance to the Main Stationary Line in Jylland.

Molluscan shells (Macoma calcarea) from the younger part of the Older Yoldia Clay (the Macoma calcarea zone, sensu Petersen in Bahnson et al. (1974)), has recently been dated by the AMS method to be in ${ }^{14} \mathrm{C}$ years around $32000-33000$ B.P. (AAR-1410 and AAR-1411).

Consequently, it is likely that the older marine strata in the lower marine part of the Skagen Well can be correlated to part of the sequence demonstrated in the Skærumhede Well (Jessen et al. 1910; Bahnson et al. 1974) covering the Eemian and the main part of the Weichselian.

Regarding the $130 \mathrm{~m}$ thick upper sequence, this is from results of the ${ }^{14} \mathrm{C}$ dates related to the time of the Younger Yoldia Sea and the Holocene, and as it appears from the dates of the sediments here is for the first time within the Danish area found in a continuous marine succession. This can be explained on the basis of the hitherto unsurpassed thickness of Late Weichselian-Holocene marine strata. Therefore, while most of the Danish area has a continental period in the time span 11000 - 7500 B.P. in ${ }^{14} \mathrm{C}$ years (Petersen 1985b), the Skagen area was so low-lying that it was continuously covered by the sea.

This is a reflection of a lesser glacial deposition and the glacio-isostatic down-pressing - the latter amounting to up to $200 \mathrm{~m}$, as seen from the amount of isostatic rebound after the waning of the ice cap over northern Denmark (Petersen 1990). However, when only Holocene dates are used, the estimated rebound of $200 \mathrm{~m}$ seems to be greater than the present dates allow when also Late Weichselian dates are used (Petersen 1999). So the low stand of sea level during the latest part of the Weichselian and Early Holocene was not to be overtaken by the isostatic uplift at any time in this area. After the final large eustatic rise in the Early Atlantic, the marine sedimentation is a dominating factor in raising the levelled sea bottom, compared to a decreasing isostatic rebound up to the Subatlantic when the isostatic rebound in Denmark expired (Petersen 1990). Here the formation of the Skagen Spit takes over, so that the last event of changing depth depends on the large quantities of sand and gravel deposited as the Skagen Spit grows to the north.

\section{The pre-Late Quaternary deposits}

In the deeper part of the Skagen Well, the base of the Quaternary is found resting on pre-Quaternary deposits of Lower Cretaceous sand. In the following description, Appendix 3 should be consulted.

The pre-Quaternary strata consist of quartz sand and gravel. From a depth of 195.15-195.30 m b.s., which is the upper part of the pre-Quaternary stratum, a mean grain size of fine sand, poorly sorted, is found (lab. no. 789.93). At a depth of 194.35-194.48 m b.s., the sediment is poorly sorted and the mean grain size is within medium sand, and this sediment also contains much quartz, but has another component in the form of stones of granitic composition.

The cumulative curve shows an even distribution of all grain sizes, which refers this sediment to be a till (lab. no. 788.93). This is also true for the overlying strata up to around $189 \mathrm{~m}$ b.s. The mean grain size is here within fine sand; however, more fine-grained parts are found. The sediment contains siderite(?) concretions with pyrite, in which imprints of Cyrena sp. are found. This might show that Jurassic deposits have been eroded. Some traces in pyrite were found as well. The whole sequence can be regarded as till. The sediment analyses from 188.57 to 187.18 give a badly sorted sediment sustaining that this is a till. Also this level contains shell fragments, one of which can be shown to be a Nuculana pernula.

\section{The Late Pleistocene}

\section{Eemian deposits}

The granulometric composition is shown from sample lab. no. 800.93. At a depth of $185.37 \mathrm{~m}$ b.s. the sediment is very fine-grained but contains only fragmented bivalves. At $185.0 \mathrm{~m}$ b.s. the marine sediment can be demonstrated by the occurrences of Dentalium vulgare in many specimens and the bivalve Kelliella miliaris also in many specimens and with connected valves.

The granulometric composition can be seen from the two levels 182.65 and $180.57 \mathrm{~m}$ b.s., samples nos 784.93 and 797.93 respectively. It appears that the sediment is very fine-grained clay to fine silt and moderately sorted in the $180.57 \mathrm{~m}$ level. Accessory finds of spatangids and ophiorids occur at the $185.0 \mathrm{~m}$ level, and pyrite formed in former burrows in the clayey material.

Also finds of fish occur, as found at the $182 \mathrm{~m}$ level, 
and under the name of other fossils also Crustacean remains have been listed. The third mollusc species found at this level is the Ophistobranch Limacina retroversa, which is found in large numbers (11 specimens in one sample) together with Kelliella miliaris (also of a number of 15 in one sample). The samples here referred to are all from the heavy weight separation of the Foraminifer samples.

The species diversity and number of specimens in the sediment appear from the sample at $182.24 \mathrm{~m}$ b.s. in which 25 specimens of Kelliella miliaris are foundmost of them with connected valves and in some parts kept in pyrite.

Trace fossils in pyrite are found in great quantities recorded in the table from all levels.

An expression of the grade of fine-grained sediment occurring at this level can be seen from the fact that only a biogene residue occurs here including the pyritiferous biogene traces - Lebenspuren. The limpid Delectopecten vitreus also appears at this level. As mentioned in the chapter on the molluscan species, the two sedentary species which today are known from the deeper part of the Skagerrak are Delectopecten vitreus and Kelliella miliaris. The latter is also found in the Turritella terebra zone in the Skærumhede Well. From $183.4 \mathrm{~m}$ b.s. Hiatella arctica is found, which occurs also at the greater depths and furthermore is a species widely extended. The occurrence of Entalina tetragonia at $183.6 \mathrm{~m}$ b.s. goes together with the occurrence of Delectopecten vitreus, both of which are found in the deeper part of the Skagerrak today, where they are part of the Amphilopsis norwegica/Delectopecten vitreus community.

To this can be added Cadulus jeffreysi found at the $184.4 \mathrm{~m}$ level. This species is widely extended in the northern part of the Atlantic down to the Bay of Biscay and into the Mediterranean. However, a single find of Siphonodentalium lobatum at $184.6 \mathrm{~m}$ b.s. points to a more Arctic environment. Such shells are found in glaciation deposits according to Muus (1959). However, the species may extend into the Lusitanian region.

From the $182 \mathrm{~m}$ level and up to $180 \mathrm{~m}$ b.s. still with a fine-grained and well-sorted sediment, Yoldiella frigida appears, which is also known from the deeper part of the Skagerrak today.

This species can be referred to the same environment as has been mentioned above - the Amphilopsis norwegica/Delectopecten vitreus community. Yoldiella frigida is known from the Turritella terebra zone in the Skærumhede sequence and the Portlandia arctica zone according to Jensen \& Spärck (1934). Kelliella miliaris and Limacina retroversa, which have been very frequent in marine layers met with under $180 \mathrm{~m}$ b.s., are no longer found above $180 \mathrm{~m}$ b.s.

\section{The Early/Middle Weichselian, marine and glacigene deposits}

Regarding the sediment which is to follow at the levels above, between 179.65 and 179.74 , it appears that the mean grain size is somewhat bigger medium sand, moderately sorted. But the most significant is found in the cumulative curve showing two maxima on the frequency curve (Fig. 91). This points to the effects of two sedimentation agents which might be a drop till effect besides the general marine sedimentation. During the examination of the samples from this level, sand and fine gravel occur, in contrast to the levels below, where only biogene remains were found, including the pyritiferous biogeneous traces. The coarser minerogene elements are found higher up in the series to the level $175.30-175.50 \mathrm{~m}$ where a fine-grained sediment with a median grain size of $0.002 \mathrm{~mm}$ reveals Arctic marine molluscs.

This is the first appearance of Portlandia arctica, which as the name tells is the characteristic mollusc of the Portlandia arctica zone in the Skærumhede sequence. However, also the presence of Yoldia hyperborea, which is known today from the Arctic and down to the Lofoten area is characteristic. This species is also found in the Portlandia arctica zone together with Nuculana pernula and Palliolum greenlandicum.

The occurrence of Macoma sp. has been added from

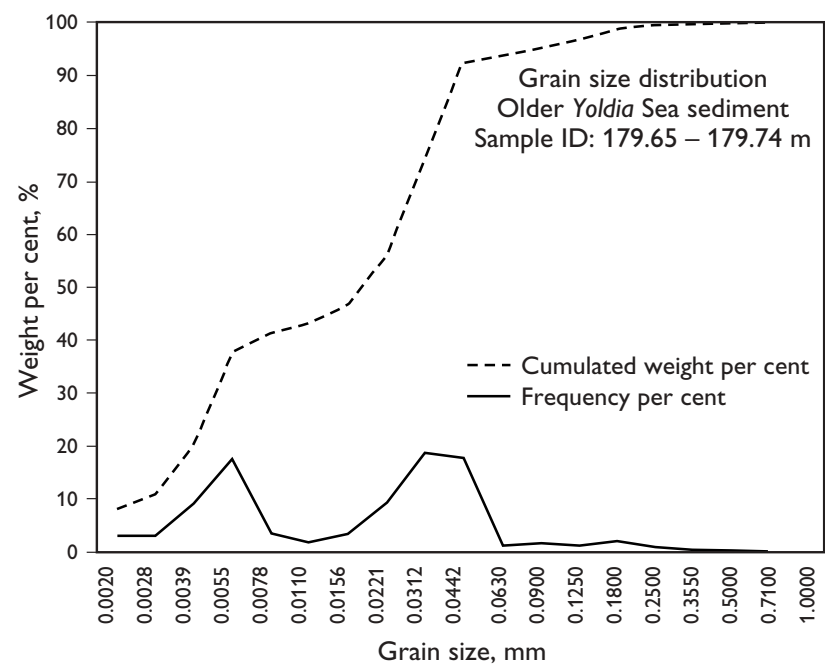

Fig. 91. The granulometric composition with two maxima on the frequency curve (lab. no. 483.93) at the 179.65-179.74 m level. 
the $177.8 \mathrm{~m}$ level but not on species level because of the fragmentary state of the shell. Both spatangids and ophiorids are found and a fragment of cirriped at the $177.8 \mathrm{~m}$ level.

At $174.4 \mathrm{~m}$ b.s. a single find of Yoldia byperborea occurs. The granulometric composition found at the 173.67-173.85 level (lab. no. 781.93) shows bad sorting in a clayey sediment with a median grain size within clay to fine silt. In this sediment fragments of Arctica islandica are found that can be regarded as being part of the redeposited material which can be found also higher up in the core. At a level of $166.5 \mathrm{~m}$ b.s. the sediment is well-sorted fine sand and regarded as fluvial. In the following $16 \mathrm{~m}$ up to $151.50 \mathrm{~m}$ b.s. the sediment is coarser, being a moderately sorted medium sand also regarded as fluvial sand. From here only some shell fragments are found and no record of fossilia varia (other fossils in Appendix 3).

In the next metres to the level of 143.83-144.00 m b.s. the mean grain size is within the medium silt grade. This is found to be a fine-grained fluvial material forming part of a glacigene complex. Also here, fragmentary molluscs are found.

\section{The Late Weichselian marine and glacigene deposits}

The first molluscs regarded as autochthonous above the glacigene complex are found at the $130.2 \mathrm{~m}$ level, so this is regarded as the upper limit of the glacigene sequence. In the interval from 141.00 and up to 130.2 $\mathrm{m}$ b.s. more shell fragments have been found - all showing signs of transport and wear. Finds of pyrite (137.8 m level), concretion (132.6 m level), and glacial stria on a stone (137.44 m level) all reflect typical features for a till deposit.

The marine shell material taken up by the glacier occurs in a fragmentary state, which is typical for redeposited material. However, it is from these strata that the absorption of gases from marine deposits has been dated. These dates form as mentioned a parallel to the age determination of the shells (Macoma calcarea) from the Skærumhede sequence where the Older Yoldia Clay fauna has been studied (Madsen et al. 1908; Bahnson et al. 1974). The ages found on Macoma calcarea shells from the Skxrumhede II Well give for the first time, on the basis of molluscs, the absolute age of around $32000-33000\left({ }^{14} \mathrm{C}\right.$ years $)$ of the younger part of the Older Yoldia Clay. Compared with the dating of the marine gases from the Skagen
Well, there is a good correlation to the stratigraphically now well-established Skærumhede sequence, so that the two cored sections found on Skagen and at Skærumhede can be regarded as deposited during the same time in the Weichselian. The Skagen sequence, however, has been strongly eroded by the ice sheet advancing during the Late Weichselian. However, the thick packet of up to $50 \mathrm{~m}$ glacial sediments consequently contains the traces (gases) of that marine environment, which has been eroded, but is hereby dated to give the maximum age of the glaciation. This age points to the glaciation event in the Late Weichselian around 20000 - 18000 B.P. (Petersen \& Kronborg 1991). However, here the upper marine sequence found in the Skagen Well will be described.

From the 131.63-131.73 $\mathrm{m}$ level and up the core the sediment is extremely fine-grained with a medium grain size of fine silt which stays as such a size up to $100 \mathrm{~m}$ b.s. It should be noted that throughout the first $15 \mathrm{~m}$ of the core from the above-mentioned level finds of coarser material occur. This is seen at the 125.89-126.00 $\mathrm{m}$ level (lab. no. 526.93), where the granulometric composition reflects two maxima on the frequency curve (Fig. 92). This is taken as a typical sign of a supplementary sedimentation which might have been caused by the melting of floating ice with the coarser sediment imbedded - a drop till effect, as found deeper in the core (Fig. 91).

This suspected Arctic influence is sustained by the occurrences of Arctic molluscs up to the 114.0-115 m level, where both Portlandia arctica and Batbyarca glacialis are present.

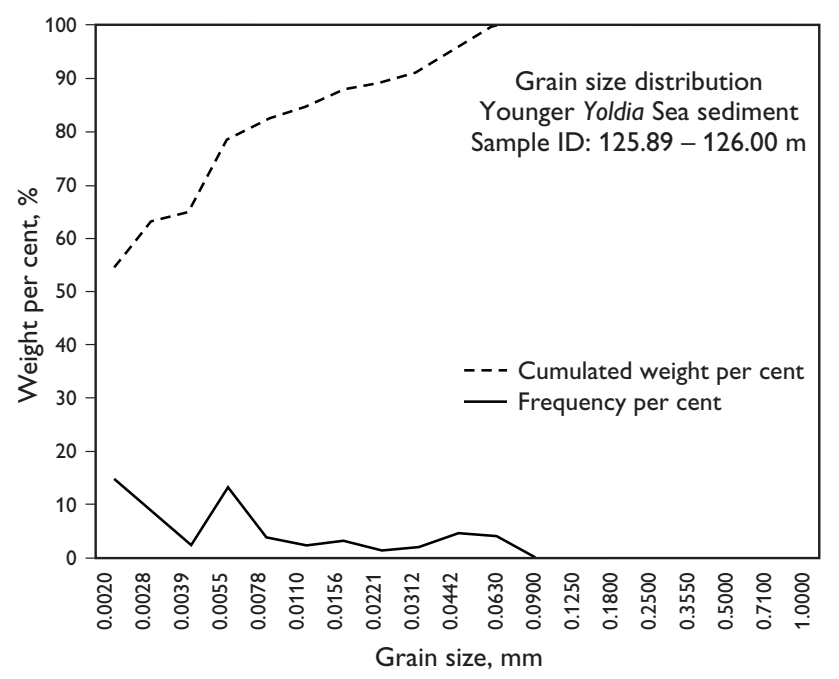

Fig. 92. The granulometric composition with two maxima on the frequency curve (lab. no. 526.93) at the 125.9-126.0 m level. 
Furthermore, species such as Nuculana pernula, Nuculana minuta and Yoldiella lenticula occur, which are known from the Older Yoldia Clay in the Skærumhede sequence.

Yoldiella frigida is the first to occur at the $130.2 \mathrm{~m}$ level in the Skagen Well. From this level several finds of ophiuroids (fragments), cirripeds and remains of pisces. However, no finds of spatangoids have been demonstrated within the whole sequence referred to the Arctic marine deposits, but they are found all the way up in the Boreal sequence (Fig. 93E; fold-out, back cover).

In the upper part of the Arctic sequence Siphonodentalium lobatum occurs at the 116.0-114.6 m level and a single find of Entalina tetragona. Occurrences of Nucula sp. and Macoma sp. are also recorded in the Arctic part, but in such a fragmented state that the species cannot be given. From the recorded faunal composition it appears that it is a deeper-water fauna. This is also supported by the fact that forms reflecting an Arctic Macoma calcarea community are not present, and the fine-grained sediment points in the same direction.

As a comment to the sedimentary environment it should be mentioned that magnetic spherical concretions have been found all through the Arctic sequence. From five levels: 117.69-117.85, 124.34-124.50, 127.39127.50, 128.13-128.33 and 132.69-132.77 m b.s. a high content of griegite $\left(\mathrm{Fe}_{3} \mathrm{~S}_{4}\right)$, which explains their magnetic quality, has been found by X-ray analysis together with quartz, calcite, feldspar and clay. Griegite has been reported as a constituent of reduced sediments. The occurrences in the Skagen Well are of interest in so far as the spherical magnetic concretions have been recorded only from the Arctic sequence.

This Arctic Sea deposit has been dated on material from the cores both foraminifers and macrofossils (Heier-Nielsen et al. 1995). From this it is seen that the actual time span ranges over $5000{ }^{14} \mathrm{C}$ years from 15000 to 10000 B.P.

The sudden change in the macrofauna, or better the abrupt stop of the occurrences of Arctic species, at the level of 114.2 to $114.00 \mathrm{~m}$ b.s. gives the PleistoceneHolocene boundary.

The transition from the Pleistocene Younger Yoldia Sea to the Holocene marine deposits is here recorded for the first time within the Danish realm with a whole series of AMS datings supporting the chronostratigraphic position, see Appendix 4.

The dates are highly significant because the molluscan finds in the older part of the marine Holocene are extremely poor. This, however, is not caused by the lack of samples from this core section, but is as will be shown dependent on the type of facies following the deposition of the youngest Yoldia Sea, which was a deeper-water deposit, followed by a Boreal deeperwater facies in the older part of the Holocene. The change from Arctic to Boreal conditions is regarded as influenced by a new current system from the Atlantic bringing in the new temperate fauna replacing the Arctic fauna of Late Weichselian age.

The change in fauna is, however, not reflected in the sedimentary record (Appendix 3, pp. 17, 21), which shows a very homogeneous clayey grain size distribution with nothing coarser than fine sand. Only in one sample (Appendix 3, p. 21, $115 \mathrm{~m}$ b.s.) at the sharp boundary between Late Weichselian and Holocene medium sand, coarse sand and gravel are observed. On this homogeneous sequence of clay to fine sand measurements of magnetic susceptibility and thermoluminescence sensitivity have been conducted.

It is worth noticing that in a diagram of magnetic susceptibility versus TL sensitivity the two samples forming the peak in the last part of the Late Weichselian also represent the more immature sediment (high susceptibility and high TL sensitivity). In contrast, the whole series of samples from the lower part of the Holocene seems more mature (low susceptibility and low TL sensitivity). So, in this way the peak can also be connected with the sudden break through of the water from the Baltic Ice Lake at Mt. Billingen, whereas the mature sediments from the Holocene may reflect the long-transported sediments introduced by the new current system from the Atlantic, bringing in the new temperate fauna in the early part of the Holocene and replacing the Arctic fauna of Late Weichselian age (unpublished data, K.L. Rasmussen and K.S. Petersen).

\section{The Holocene}

As mentioned earlier, the transition from the Arctic Younger Yoldia Sea to the oldest Holocene marine deposits is not to be seen from the sediment analyses except for the occurrences of griegite and some coarser material in the Arctic part. This appears when the cumulative curves from the 125.89-126.0 and 113.60$113.70 \mathrm{~m}$ levels from the Arctic and Boreal part (Figs 92, 94, lab. nos 526.93 and 522.93 respectively) are compared. The median grain size is for both samples fine silt, see Appendix 3, p. 21.

Considering the many samples analysed within the 


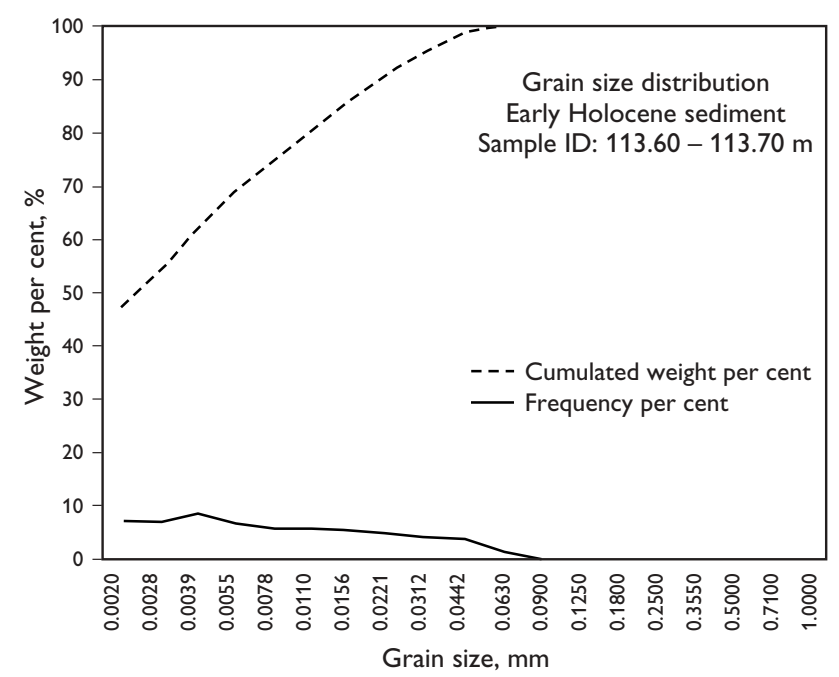

Fig. 94. The cumulative curve from the $113.60-113.70 \mathrm{~m}$ level, lab. no. 522.93

lower part of the Holocene up to the $100 \mathrm{~m}$ level, which is dated to be around the Boreal-Atlantic boundary, only very few molluscan species have been found; also the number of specimens is low.

\section{The Preboreal-Boreal $10000-8000{ }^{14} \mathrm{C}$ years B.P.}

In the Preboreal-Boreal sequence only Parvicardium minimum has been found in more than a single find together with Mysella bidentata. However, three other genera are recorded: Cardium, Abra and Lyonsia.

Parvicardium minimum is known from the deeper part of the Skagerrak today and is found up to a depth of $30 \mathrm{~m}$ in the Kattegat. It is recorded also from the Eemian in the Skærumhede series. Compared with the occurrences of Mysella bidentata also in this core level at Skagen one can imagine a deeper-water environment, because Mysella bidentata is also found to great depth $(600 \mathrm{~m})$ today in the Skagerrak.

Spatangoids, apparently in great quantities - considering the many fragments - are found and in a lesser degree fragments of ophiuroids, which were also recorded from the Arctic part.

From the family Spatangidae, five genera are known in Nordic waters. From the Skagen Well at a depth of 108.34-108.56 m b.s. a well-preserved species of Brissopsis lyrifera (Forbes) has been collected (Fig. 95). This species lives only on pure muddy bottoms and totally embedded in the sediment.

As seen from the grain-size distribution from the

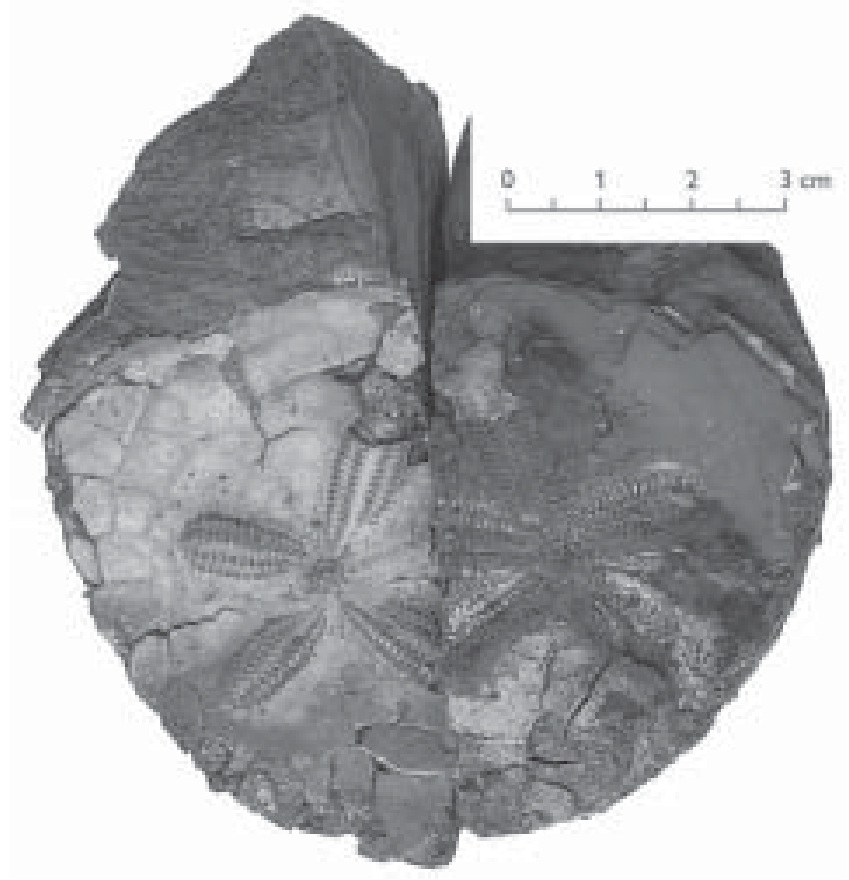

Fig. 95. The well-preserved Brissopsis lyrifera (Forbes) from the 108.34-108.56 m level. MGUH 25404.

level of 107.90-108.00 $\mathrm{m}$ b.s., this part is a fine-grained sediment. From the 109.39-109.50 m level the core section revealed a cut through the traces of a spatangoid similar to those that Brissopsis lyrifera could leave, with the typical backfilling (Bromley 1990, fig. 5.11; see Fig. 96).

Brissopsis lyrifera can be found in great quantities in the northern part of the Kattegat and Skagerrak, while it might be found in the Øresund but not in the Bælt Sea, the Baltic and the Limfjord region, according to Mortensen (1924).

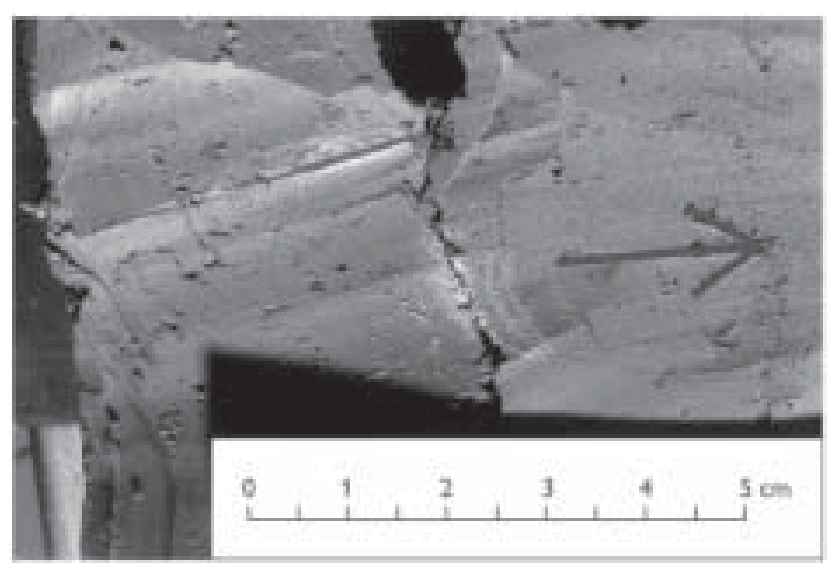

Fig. 96. Trace from the 109.39-109.50 m level. Might be similar to that of Brissopsis lyrifera. 
Also other spatangoids might be found in the Skagen cores in the huge material of fragments. From the older strata the genus Echinocardium has been recorded earlier from the Skærumhede series by the author, and Echinocardium cordatum has been found in the Cyprina Clay from the Eemian (Madsen et al. 1908).

So poor in molluscan species this community from the Early Holocene appears to be, one may pay attention to the abundant of remains of starfishes and echinoids which can be seen as a dominating element in this environment. In this way the sea bottom of those days was controlled by the echinoderms eating up most of the larvae of molluscs, as described by Thorson (1961). If one should be compared with a present-day community, it must be the Maldane-Ophiura sarsi community in which besides Ophiura sarsi, Brissopsis lyrifera is found as the only often found larger animal (Thorson 1968).

The Maldane-Ophiura sarsi community replaces the Amphiura community at depths of around $150 \mathrm{~m}$ and deeper in the Skagerrak.

A single find of Pisces (100.3-100.5 m) has been recorded and a few finds of plant remains and pyritified traces (chondrites?).

These rare finds of marine deeper-water facies from the very last part of the Pleistocene and the earliest Holocene will contribute to our knowledge of the land and sea configuration during the so-called Continental period (Petersen 1985b).

Considering the sedimentation rate during the first 2000 years of the Holocene, viz.: through the Preboreal and the Boreal from which there have been only a few records earlier within the Danish area, it is seen to be around $7.5 \mathrm{~m}$ per 1000 years. This is higher than the sedimentation rate for the Younger Yoldia Sea, as found also in the Skagen Well record of $3 \mathrm{~m}$ per 1000 years. When this is given in calendar years, the differences are even bigger, because then the sedimentation of $15 \mathrm{~m}$ in the Younger Yoldia Sea took about 6000 calendar years and still about 2000 calendar years in the Preboreal and Boreal seas within the Skagen area (Petersen \& Rasmussen 1995a, b).

Regarding the sediment, $50 \%$ is found to be clay in the Younger Yoldia Sea - and in some parts at the level of 117.29-117.40 m b.s. around 63\% - while during the Preboreal-Boreal the clay content has fallen from around $40 \%$ at the $113.60-113.70 \mathrm{~m}$ level to 20 $30 \%$ at the $100 \mathrm{~m}$ level.

\section{The Atlantic $8000-5000{ }^{14} \mathrm{C}$ years B.P.}

From the dates (Heier-Nielsen et al. 1995) the Atlantic covers the cored section from 100 to $80 \mathrm{~m}$ b.s. Here the sediment in the oldest part has 30-20\% clay, falling to a content of $15 \%$ clay in the youngest part at the 80.60-80.70 m level (see Fig. 93A).

Throughout the Atlantic the echinoids still dominate the samples and among these the spartangoids, as in the Preboreal and Boreal. However, here small gastropods occur: Melanella lubrica, Odostomia umbilicaris, and Eulimella scillae.

Melanella lubrica is regarded as an ectoparasite on holothuroids, and Odostomia umbilicaris is often found together with Mytilus adriaticus. However, the latter bivalve has not been found in the Skagen Well material. It should be mentioned that the Odostomia species are difficult to determine (Fretter et al. 1986, p. 605) and no less so in subfossil material.

Furthermore, Onoba vitrea and Aclis minor are found in the younger part of the Atlantic, where the determination of Onoba vitrea is taken with some reservation because the three other species Odostomia semicostata, Odostomia aculeus, and Odostomia proxima are very much alike and difficult to tell apart on shell features alone.

Aclis minor belongs to a large group of predatory gastropods that mostly and perhaps always (cf. Fretter \& Graham 1962) are associated with echinoderms.

From the Atlantic single finds of Parvicardium minimum from the $96 \mathrm{~m}$ level and Spisula subtruncata at the $86 \mathrm{~m}$ level occur. Spisula subtruncata is found next at the $73 \mathrm{~m}$ level in the Subboreal, but becomes the dominating bivalve at the $30 \mathrm{~m}$ level, which can be referred to the younger part of the Subatlantic. This depth is also within the range where this bivalve is found in large amount in the present-day Danish seas.

From the Atlantic the predatory gastropod Lunatia alderi occurs. This species is most probably the one which has bored into the many molluscs found in the overlying strata, but has not been recognised by its traces in the sparse material from the Atlantic.

Fragments of Abra sp. and Macoma sp. occur in the cored section from the Atlantic, and from the 80.60$80.70 \mathrm{~m}$ level also finds of Pisces and crustaceans have been recorded, as seen in Appendix 3.

It appears that also in the Atlantic the sampling reveals a deposit with low diversity and few specimens of molluscs, where the echinoderms dominate as in the Preboreal and the Boreal sequence. However, considering the older Holocene deposits which were ten- 
tatively referred to the Maldane-Ophiura sarsi community, the one from the Atlantic can on the basis of the molluscs and the still dominating Echinoderms be regarded as another of the deeper-water communities found in the present-day deeper water in Skagerrak. Here it should be the Amphiura community, which as mentioned earlier is found above depths of $150 \mathrm{~m}$.

\section{The Subboreal $5000-2500{ }^{14} \mathrm{C}$ years B.P.}

The following $20 \mathrm{~m}$ of the Skagen Well cover the Subboreal, 80 to $60 \mathrm{~m}$ b.s. The sedimentation rate can be estimated to be $8 \mathrm{~m}$ per 1000 years, a slight rise from the $6.6 \mathrm{~m}$ per 1000 years found during the Atlantic.

The clay content falls in this part to below 10\%, and the coarse silt and fine sand fractions become the dominating grain sizes. The material is well sorted. Fig. 93A, C.

In all the sampled cores within this section fragments of echinoderms occur - mostly spatangoids as found earlier - but the diversity of mollusc species is higher, up to 10 different species in one sample and several with five to seven species in each. However, the number of specimens is still low and most of the finds are of single specimens.

Only Onoba vitrea is found in a number of eight specimens in one sample (the $67.0 \mathrm{~m}$ level). Among the other species, only Lunatia alderi can be mentioned occurring in a number of eight within the whole section.

From the $73.0 \mathrm{~m}$ level Turritella communis occurs with boring of predatory gastropods - probably Lunatia alderi.

Furthermore, Eulimella scillae and Retusa truncatula are found from the $67 \mathrm{~m}$ level and Mysella bidentata together with Corbula gibba at the $65.6 \mathrm{~m}$ level. The latter will be more common in the above-lying strata belonging to the Subatlantic.

From the Subboreal sequence, one of the very few finds of Polyplacophora occurs sitting in the sediment, represented, however, only by one plate which does not allow further determination by the author.

Within the interval from $75.0 \mathrm{~m}$ to $72.0 \mathrm{~m}$ three finds of Turritella communis have been recorded. This is one of the characteristic species on the level muddy bottoms.

Nuculana minuta which has been found also in the Arctic Younger Yoldia Clay is here recorded for the first time in the Holocene in the Skagen Well. There are several finds of Nuculana minuta from the Subboreal, and it is found in the present-day Kattegat on muddy bottoms at depths of more than $20 \mathrm{~m}$. This fits very well with the occurrences of Turritella communis.

Acanthocardia echinata is also found for the first time and here recorded from $78.0 \mathrm{~m}$. This species occurs on mixed bottoms and clay bottoms at depths of from 10 to $150 \mathrm{~m}$.

Also Phaxas pellucidus occurs for the first time in the Skagen Well during the Subboreal. This mollusc occurs in general at depths of between 10 and $50 \mathrm{~m}$, often together with Abra alba, also found in this section of the well.

The first occurrences of Chamelea striatula and Corbula gibba are in the Skagen Well during the Subboreal.

Chamelea striatula is one of the most common of the Danish marine bivalves but is connected to the sandy bottoms. According to Jensen \& Spärck (1934), it is not found in the Kattegat at depths greater than 50 $\mathrm{m}$, because the sandy bottom in this region goes no further out and the species is rarely taken on clayey bottoms. In this connection it should be noticed that just around the $75 \mathrm{~m}$ level, where Chamelea striatula occurs for the first time in the Skagen Well, the sediment changes to coarse silt with more than $50 \%$ fine sand.

Finally, at 61.09-61.14 m, is the first occurrence of Tellimya ferruginosa. This species will also be more common in the Subatlantic from the $30 \mathrm{~m}$ level. Tellimya ferruginosa is often connected with the occurrence of Echinocardium cordatum but can also be found free living (Jensen \& Spärck 1934).

The many new species - new through time in the Skagen Well - introduced in the Subboreal point to water depths around $50 \mathrm{~m}$ with characteristic species from the present-day community such as Turritella communis and Chamelea striatula - the Venus community.

The changes to a more sandy sediment are perhaps the background for the occurrences of the new species. However, the echinoids have also decreased and this may explain the more prolific mollusc faunas, for the toll of eaten molluscan larvae taken by the echinoderms is no longer so high (cf. Thorson 1961).

\section{The Subatlantic $2500-{ }^{14} \mathrm{C}$ years B.P.}

The uppermost $60 \mathrm{~m}$ of the Skagen Well belongs to the Subatlantic. In general the $60 \mathrm{~m}$ cored section that falls within the Subatlantic can be divided into two parts of an equal length of $30 \mathrm{~m}$ : the lower $30 \mathrm{~m}$ with 
a clay content of 30-40\% of well-sorted sediment, and the upper $30 \mathrm{~m}$ mainly consisting of fine to medium sand with few intercalations of gravel.

Regarding the dated part of this upper sequence (Heier-Nielsen et al. 1995, table 1) - from 30.25 to 12.75 $\mathrm{m}$ b.s. the sedimentation is $17.50 \mathrm{~m}$ during 210 years from A.D. 950 to A.D. 1160. This gives a sedimentation rate of about $80 \mathrm{~m}$ per 1000 years. In this case showing a fine example of the building up of the Skagen spit, where the coarser material occurs as part of the long-shore transport, and deposited in foreset beds.

\section{The older Subatlantic}

The older part of the Subatlantic covers the interval from 60 to $30 \mathrm{~m}$ b.s. This section shows a slight coarsening upwards and a sedimentation rate of $30 \mathrm{~m}$ per 1000 years. The faunal composition can be analysed on the basis of 50 samples with a higher species diversity than found in the Subboreal. Some of the species are new to the record from the Skagen Well.

Hinia pygmaea appears for the first time at the 42 $\mathrm{m}$ level, as well as Hinia reticulata. They both belong to the sublittoral zone and are found on muddy bottoms. Mangelia brachystoma, which first occurred at the $58 \mathrm{~m}$ level, also belongs to the sublittoral fauna, but it occurs on sand and sandy muddy bottoms.

Polygireulima sinuosa is an ectoparasite on echinoderms which are still common and constitute a part of every one of the samples, but it has been found only within the level 38.19-38.24 m.

The first littoral species, Mytilus edulis, occurs at 49.14-49.24 m, and from this level it occurs regularly upwards, but only in small numbers until the $31 \mathrm{~m}$ level, where it is found in greater quantities. This species can be found out to $40 \mathrm{~m}$ depth, but must nevertheless be considered an eulittoral species where its occurrence is most abundant. The young specimens are often found on the vegetation.

Also Chlamys varia is common in the coastal zone and occurs at the 32.85-32.90 m level.

Heteranomia squamula is epifaunal on hard substrates but also on algae and crustaceans. It has a wide occurrence from the littoral zone out to a depth of $100 \mathrm{~m}$. In the Skagen Well it is confined to the Subatlantic part.

Thyasira flexuosa is today a common bivalve on clayey bottoms from $20 \mathrm{~m}$ to $100 \mathrm{~m}$, but it has been found only in two samples from the older Subatlantic. This is hard to explain, as it has a wide extension within the whole of the North Atlantic area (Jensen \& Spärck
1934), and in numbers it is one of the most dominant species on the muddy bottoms which according to the sediment analysis have been prevalent for most of the Holocene in the Skagen area.

Turtonia minuta, belonging to the species from the coastal zone, is found in a single specimen at 39.85$40.02 \mathrm{~m}$. It is not recorded from the recent Danish fauna, but lives off the Norwegian west coast and is found subfossil in the Limfjord region.

At $47.30-47.35 \mathrm{~m}$ is the youngest record of Parvicardium minimum, which was one of the few species occurring in the older Holocene reflecting deeper water.

A single find of Angulus tenuis is at 55.30-55.35 m. The common occurrence of this species starts at the 30 m level.

Also Donax vittatus occurs at 35.90-36.00 m level which must be seen as outside the general occurrence of this species, which is from littoral to around the 20 $m$ depth Donax vittatus is found within the high energy zone.

A single find of Abra prismatica at $49.90-42.00 \mathrm{~m}$ is within the general depth interval for this species (20$60 \mathrm{~m}$ ).

In connection with the depth indications given in the well in metres below surface and the common depth intervals indicated by various authors for the molluscan species, it is possible to use the actual depth recorded in the well as the living depth for the subfossil fauna found in the Skagen Well during the younger part of the Holocene. This because of the expiring isostatic movement and only little eustatic changes during the Late Holocene (Petersen 1991b).

Corbula gibba, which was also found during the Subboreal has in the Subatlantic an even occurrence through the older part.

Barnea candida, normally only found out to a depth of $30 \mathrm{~m}$, occurs in the well already at the 51.54-51.59 $\mathrm{m}$ level, although only found in fragments.

Cochlodesma praetenue which was found in the Eemian at $183.77-184.00 \mathrm{~m}$ b.s. is also found in the Subatlantic at $43.19-43.24 \mathrm{~m}$. This species is rare in Danish waters and has been taken alive only once north-east of the island of Læsø. However, shells have been found elsewhere in the Kattegat region, Jensen \& Spärck (1934). It has a wide occurrence from the littoral zone and out to $110 \mathrm{~m}$ on different bottom types.

Finally Thracia phaseolina shall be mentioned. This species occurs to depths around $50 \mathrm{~m}$ on clayey bottoms.

As mentioned above, the echinoderms are also found 
in the Subatlantic represented by the fragments of spatangoids. Also cirripeds occur in still higher quantities up towards the $30 \mathrm{~m}$ level (Appendix 3, p. 6). Furthermore, there are single finds of Pisces and other fossil remains such as crustaceans (other fossils in Appendix 3). However, also serpulae are found and may have settled on the shells of the other animals as the crustacean carapax.

\section{The younger Subatlantic}

The increasing number of cirripeds in the upper $30 \mathrm{~m}$ should probably be regarded as allochthonous, since they occur together with the coarser material during the formation of the advancing Skagen Spit.

The change in the upper $30 \mathrm{~m}$ to coarser material also introduces new forms of molluscs that are characteristic of the littoral facies and high-energy coastal situation still prevailing in this area today.

The description of the upper $30 \mathrm{~m}$ is, as mentioned earlier, based on the Skagen IV Well $50 \mathrm{~m}$ away from the Skagen III Well and at the same level (+ $1 \mathrm{~m})$. This was done because only washed samples were obtained from the upper $30 \mathrm{~m}$ of the Skagen III Well, and such samples could not form the best basis for a uniform description of the whole sequence - especially the necessary quantitative treatment of the molluscan faunas could not be fulfilled in that way. Furthermore, a total of 29 grain-size analyses have been made within this part of the column, showing two sequences of well-sorted sediment coarsening upwards, with a sorting coefficient lower than 2 (Fig. 97).

In order to control the degree of transported shell material, size analyses and counts on right and left valves have been considered relevant with such a highenergy near shore sedimentation (Fig. 98).

Especially the most prevalent bivalve within these uppermost $30 \mathrm{~m}$, Spisula subtruncata, has been counted. Also observed borings have been figured in Appendix 3, to be seen in connection with the actual finds of the predatory gastropods. This is done in order to show the degree of mutual connection in the molluscan assemblages, between predatory elements and their prey.

The building-up of the upper $30 \mathrm{~m}$ took place within a very short period of time, and the sedimentation rate of this interval is estimated to be around $70 \mathrm{~m}$ per 1000 years. This high sedimentation rate has a serious effect on animal life.

The dates on the building-up of the Skagen Spit lead to the conclusion that the extension of the coast line to the place where the wells have been sunk took place around A.D. 1400.

Taking into account that the final history of the coastal development takes place as a near-shore and littoral deposition history, the actual development on a west coast site similar to the Skagen area has been analysed. This has been done by way of several van Veen grab samples - altogether 61 outside the Agger Tange complex in the westernmost part of the Limfjord (Petersen 1994a). These investigations focused on the bivalves, evaluating their degree of being autochthonous from the preservation with both valves together, one valve but whole, a fragmented state or a rolled fragment. These observations have been summarised in Appendix 5.

The newcomers of molluscs from the Skagen Well will be mentioned. These also represent the species earlier known to live close to the recent Danish waters and species new compared to what is known to be part of the recent Danish fauna.

This part of the record has the highest diversity and number of specimens compared to other sections of the Skagen Well. The mean species diversity per sample shows a rise compared to the older part and reflects the new sedimentary facies. However, the near to shore situation also puts forward the question of whether part of the faunas, if not all, may have been reworked.

Eliminating the uppermost ten samples covering the $5 \mathrm{~m}$ which can be regarded as the medieval shore. First the species represented by only few finds that are commonly found in great quantities will be discussed.

Lacuna pallidula occurs only as a single find at 30.0$30.5 \mathrm{~m}$ level. This species occurs on Fucus serratus and in great quantities from the littoral and to a depth of $70 \mathrm{~m}$. Hydrobia ulvae occurs normally in high numbers in shallow water. In the Skagen Well it has been recorded from only two levels (11.70-11.80 $\mathrm{m}$ and 25.0$25.5 \mathrm{~m}$ ) and with few specimens. Rissoa violacea is connected with seaweeds and found from the tidal zone to a depth of $50 \mathrm{~m}$. Here the only finds are from the 27.0-27.5 and 28.0-28.5 m levels. Also Bittium reticulatum appears not to be part of the environment, since this species has only one occurrence at the 22.0$22.5 \mathrm{~m}$ level. This species lives on Zostera, as do other of the above-mentioned species.

It can be concluded that the upper $30 \mathrm{~m}$ section of the well lacks the normal abundance of epifaunal elements connected with vegetation. This is also in good accordance with the high rate of sedimentation. 


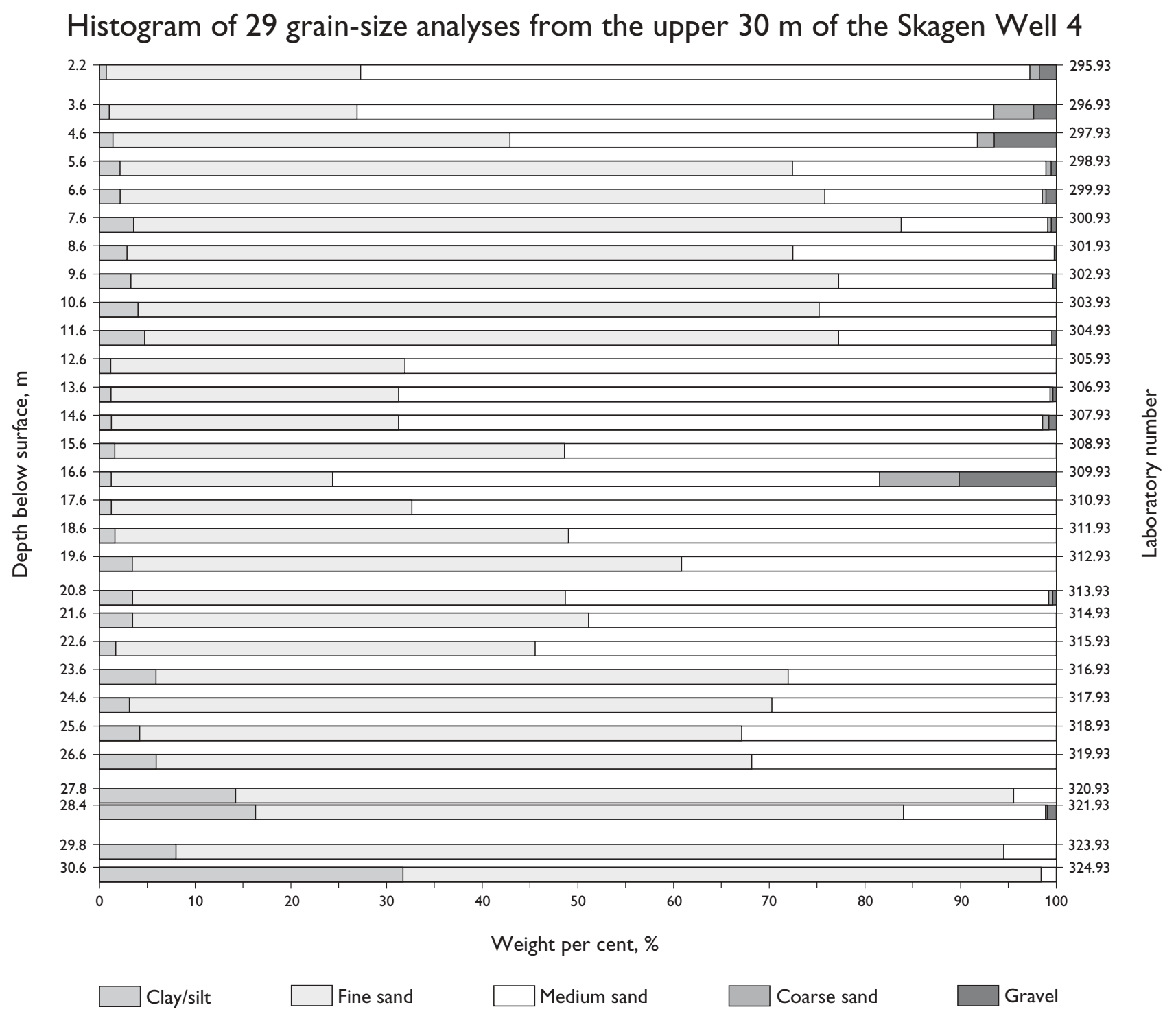

Fig. 97. Histogram of 29 grain-size analyses from the upper $30 \mathrm{~m}$ of the Skagen Well 4, showing two coarsening-upwards sequences.

Among the gastropods occurring in the upper part of the well, Aporrhais pespelicani occurs in the interval from $22.0-22.5 \mathrm{~m}$ to the $11.0-11.5 \mathrm{~m}$ level. This species is regarded as sublittoral from depths of 10$180 \mathrm{~m}$ on a sandy muddy bottom or muddy bottom. However, it has been found in large quantities as empty shells on the shore of the east coast of Skagen. This was rather puzzling until it was explained that the hermit crab might have been the actual agent bringing the shells on shore (G.H. Petersen, personal communication 1998).

The occurrence of Lunatia montagui is restricted to the $20.0-20.5 \mathrm{~m}$ level, while Lunatia alderi is rather frequent in the core samples. The impact of these predatory gastropods on the fauna -15 species have been recorded with such borings, including some of the Lunatia species themselves - has been quantified in Appendix 3.

The high number of Lunatia alderi in the upper 30 $\mathrm{m}$ is in accordance with the preferred environment of clean sand of this species.

A new neogastropod to the fauna of the well is the Buccinum undatum from the 11.0-11.5 m level, while Hinia pygmaea now becomes common, occurring in most of the samples from the $28.0-28.5 \mathrm{~m}$ level to 6.0$6.5 \mathrm{~m}$ b.s. and represented in many specimens - some of them bored by predatory gastropods, as seen in Appendix 3.

The small gastropod Oenopota turricula has a wide depth range (20-200 m), so the single finds at the 23.5- 
Fig. 98. Size histograms for Spisula subtruncata in the upper part of the Subatlantic sequence, the 29.0-29.5 m level to the $5.0-5.5 \mathrm{~m}$ level, with ratio on left and right valves from the $29.0-29.5 \mathrm{~m}$ level to the $11.0-11.5 \mathrm{~m}$ level.

\begin{tabular}{|c|c|c|c|}
\hline \multicolumn{4}{|c|}{ Valves: Spisula subtruncata } \\
\hline $\begin{array}{l}\text { Depth below } \\
\text { surface, } m\end{array}$ & Number of valves & $\begin{array}{r}\text { Relative size } \\
\text { distribution }\end{array}$ & $\begin{array}{l}\text { Left/right valves } \\
\text { ratio }\end{array}$ \\
\hline $5.0-5.5$ & 125 & & \\
\hline $6.0-6.5$ & 48 & & \\
\hline $7.0-7.5$ & 109 & & \\
\hline $8.0-8.5$ & 147 & & \\
\hline $9.0-9.5$ & 311 & & \\
\hline $10.0-10.5$ & 321 & & \\
\hline $11.0-11.5$ & 442 & & \\
\hline $12.0-12.5$ & 569 & & \\
\hline $13.0-13.5$ & 278 & & \\
\hline $14.0-14.5$ & 1129 & & \\
\hline $15.0-15.5$ & 4332 & & \\
\hline $16.0-16.5$ & 1201 & & \\
\hline $17.0-17.5$ & 113 & & \\
\hline $18.0-18.5$ & 85 & & \\
\hline $19.0-19.5$ & 166 & & \\
\hline $20.0-20.5$ & 826 & & \\
\hline $21.0-21.5$ & 98 & & \\
\hline $22.0-22.5$ & 68 & & \\
\hline $23.0-23.5$ & 59 & & \\
\hline $24.0-24.5$ & 14 & & \\
\hline $25.0-25.5$ & 0 & & \\
\hline $26.0-26.5$ & 79 & & \\
\hline $27.0-27.5$ & 75 & & \\
\hline $28.0-28.5$ & 92 & & \\
\hline $29.0-29.5$ & 39 & $\begin{array}{l}\text { Size, } \mathrm{mm} \\
\quad 0.5>0.0>4.0>8.0\end{array}$ & $\begin{array}{l}\text { Right } \\
\text { Ratio 1:1 }\end{array}$ \\
\hline
\end{tabular}

$21.0 \mathrm{~m}$ level most probably reflect that only in this part of the well does the clean sandy bottom occur which is preferred by Oenopota turricula.

Of the heterogastropod newcomers in the upper section, Graphis albida from the 25.0-25.5 m level can be mentioned. This species is not recorded among the recent Danish molluscs (Jensen \& Knudsen 1995). It is found sublittorally out to a $30 \mathrm{~m}$ depth.

Hemiaclis ventrosa occurs at the 30.0-30.5 mand 11.0$11.5 \mathrm{~m}$ levels, but it is recorded in recent waters at a much deeper level: 100-200 m. Neither this nor the species mentioned above is recorded from Danish waters.

Vitreolina philippii, occurring within the interval from 29.5 to $7.0 \mathrm{~m}$ with seven specimens, is known from the recent Danish fauna and is noted as sublittoral to a depth of $200 \mathrm{~m}$. This gastropod is a parasite on echinoderms, as the other Eulimidae. Echinoderms are still present in the material as seen from Appendix 3.

From the 15.0-15.5 m level, finds of Chrysallida decussata occur, which is also recorded by Jensen \& Knudsen (1995). This species occurs at the depth interval of 14-40 m.

Turboniella acuta has been recorded from Danish waters by Jensen \& Knudsen (1995) although rare. The occurrence of this species in the Skagen Well is at the 21.0-21.5 $\mathrm{m}$ and 20.0-20.5 m levels with, two wellpreserved specimens.

Among the ophistobranchs there are some fragmentary finds which have not been identified to species 
level, but species such as Retusa truncatula and Cylichna alba are found also in the upper part of the well.

A fragmentary scaphopod from the 15.0-15.5 m level has not been referable to species level.

Among the bivalves, many are new to the already mentioned fauna from the well, and the number of specimens is for many of the species very high in comparison to what has been recorded from the older strata.

Of Palaeotaxodonta, Nucula nitidosa is found and represented all through the interval from 29.5 to 13.0 $\mathrm{m}$ b.s., occurring on sand bottom, which is the preferred substrate. Also Nucula nucleus is found within the interval from 30.5 to $8.0 \mathrm{~m}$ b.s. with many (13) specimens, part of them bored as the presiding species by the predatory gastropods.

In the Subclass Pteriomorphia, species from Mytiloida and Pterioida such as Musculus discors at the 28.028.5 level and Mytilus edulis in large quantities (113 specimens) are found, albeit most of the latter as juveniles. From the 28.0-29.5 m level individuals are found (with both valves). This latter species is typical in the littoral zone, but may occur at depths out to $40 \mathrm{~m}$.

Pectinidae have been found, but all in fragments, in the interval 25.5-12.0 $\mathrm{m}$ b.s.

Ostrea edulis occurs in the interval $28.5-7.0 \mathrm{~m}$ b.s. mostly as juveniles.

The Subclass Heterodonta, from where most of the found bivalves come also includes the species most often found and characteristic of the youngest part of the marine sequence.

Mysella bidentata is recorded from the entire Holocene, although only a few specimens are present in the Early Holocene. In the latest Holocene as the present $30 \mathrm{~m}, 125$ specimens have been found. The closely related Tellimya ferruginosa occurs apart from a single find at the 61.09-61.14 m level, from the $29.5 \mathrm{~m}$ level where it is common up to $8.0 \mathrm{~m}$ b.s. Both of these species have specimens bored by the predatory gastropods. Tellimya ferruginosa is a commensal on Echinocardium cordatum, but can also be found on its own in the sediment.

Mactra stultorum has been found only in the upper part of the cored section and can be seen as connected with the clean sand that is the type of bottom preferred by this species. On a suitable bottom it may be found out to a depth of $60 \mathrm{~m}$.

Spisula subtruncata, which has a wide distribution from the littoral zone and out to a depth of $200 \mathrm{~m}$, can be found both on muddy and on sandy bottoms. It dominates the uppermost part of the sequence, with 11085 specimens! In recent waters on sandy bottoms this species is one of the most common bivalves in the Kattegat at depths between 20 and 30 m (Jensen \& Spärck 1934). On the cored material from the Skagen Well size histograms and counts on left and right valves have been made in order to ascertain from such measurements whether the shell material is autochthonous/ parautochthonous. As seen from the figures in Fig. 98, it appears that there is an even representation of the left and right valves, and the size histograms reflect a life assemblage which also might appear from the wellpreserved gracile valves.

The borings counted on valves of this species make it clear that Spisula subtruncata must have been the preferred victim of the predatory gastropods in this molluscan assemblage. At the 15.0-15.5 m level around $10 \%$ of the specimens are bored (2723 individuals out of which 268 have been bored). Individuals (with both valves) have been found up to the 21.0-21.5 m level, where also other bivalves have been found with closed valves. However, the most even occurrence of leftright valves also at the 15.0-15.5 m level (2147-2105 respectively) may speak in favour of an autochthonous state also at this depth. The size histogram from the same level points to the same conclusion (see Fig. 98). By way of the same kind of measurements it is possible to extend the possible life-assemblages up to a level of 10.0-10.5 m b.s., where the material still is present in such quantity that the measurements can be taken as bearing. Investigations performed on nearshore deposits off the west coast of Jylland in the Agger Tange area given in Appendix 4 support the view that lifeassemblages can be found near to shore at depths of up to 6-7 m.

Almost all the AMS datings in the upper part of the well have been based on Spisula subtruncata, and these datings all fall within the right relative age according to their respective levels. This is not the case with the date on Donax vittatus, which has also been dated within the upper $30 \mathrm{~m}$ interval. As shown on the dating diagram (Heier-Nielsen et al. 1995; Appendix 3), the Donax vittatus age clearly appears as an older element in a younger part of the section. However, Donax vittatus will be commented upon later in the text.

Solenidae species often occur in the upper part of the sequence, but often in a fragmentary state. However, Phaxas pellucidus is common in the interval between the 30.5 and $20.0 \mathrm{~m}$ level, where it is found in several specimens in some of the samples. It lives on different bottom types from the sublittoral at a depth of $4 \mathrm{~m}$ out to a depth of $150 \mathrm{~m}$. However, in the Skagen Well there is only a single occurrence at 73.39-73.44 $\mathrm{m}$ b.s. 
One of the dominating bivalves is Fabulina fabula, which only occurs within the interval $28.5-4.0 \mathrm{~m}$ b.s. Some of the specimens have been the victims of the predatory gastropods. This species prefers a bottom type of fine sand, which might explain the interval of occurrence in the Skagen Well, where there are sandy layers only in the uppermost $30 \mathrm{~m}$. On a suitable bottom this species goes out to a depth of $50 \mathrm{~m}$.

Also Tellina pygmaea and Angulus tenuis occur in the upper part of the sequence and only there, with the exception of a single find of Angulus tenuis at the $55.30-55.35 \mathrm{~m}$ level. This is outside the general occurrence of this shallow-water species normally found from the intertidal zone out to a depth of $10 \mathrm{~m}$.

Donax vittatus, which is found regularly in the interval from the $27.5-4.0 \mathrm{~m}$ level, but often in a fragmentary state, is a typical high-energy coastal form on a sandy bottom. As already mentioned in connection with the dates, Donax vittatus also occurs as an allochthonous element, which can be seen from the many rolled fragments of this sturdy shell. Its occurrence out to a depth of $20 \mathrm{~m}$ off high-energy shores characterises in the best way the situation by the building up of the Skagen Spit System. The species is not found in the Kattegat region and is absent from the inner part of the Limfjord.

Garifervensis is found only in this upper part of the Skagen Well from the 27.5 to $23.0 \mathrm{~m}$ level. Accordingly, in Danish waters it is known from a depth of 15-40 $\mathrm{m}$ on mixed bottoms and sometimes on sandy bottoms.

Through most of the Holocene, fragments of the genus Abra have been found. Abra nitida, which has a wide depth distribution from the sublittoral zone out to a depth of $200 \mathrm{~m}$, has been found through the last part of the Holocene from the 71.89-72.00 m level to the $10.70-10.80 \mathrm{~m}$ level mostly in single specimens. This species has its main distribution today in the deeper parts of the Skagerrak and the Kattegat on muddy bottoms.

A single find of a rolled fragment of Arctica islandica occurs at $14.70-14.80 \mathrm{~m}$, which is the only find besides the fragment from the glacial series at the 173.67$173.85 \mathrm{~m}$ level. However, the washed samples have given another specimen also from the Subatlantic (Appendix 2).

Chamelea striatula is the characteristic animal of the Venus community on a sandy bottom in the North Sea and the Kattegat. At Skagen it occurred already at the 76.34-76.50 m level (late Subboreal). At this depth a change of weight per cent of clay takes place (from $13.7 \%$ to $7.8 \%$ ), and the fine sand component becomes the dominating grain size with a weight per cent of 54.9. From the $30 \mathrm{~m}$ level, Chamelea striatula is more common, and specimens with connected valves occur up to 21.0-21.5 $\mathrm{m}$ b.s., many of them bored by predatory gastropods, as shown in Appendix 3. From the point of view that also other bivalve species have been found as whole individuals up to the $20 \mathrm{~m}$ level, it can be regarded as the well-established limit for an autochthonous occurrence of the molluscs. However, as seen from the observations off the Agger Tange area given in Appendix 5, there will always be an element of allochthonous material in such a high-energy coastal environment which should be taken into account also for the Skagen area regarding the uppermost part of the sequence from the Skagen Well.

A single find of Timoclea ovata is also found in the upper part of the section at the $27.0-27.5 \mathrm{~m}$ level. This species is today found at a greater depth than Chamelea striatula, but is not very numerous.

Within the Order Myoida, Corbula gibba is also well represented in the upper section, with individuals found up to a level of 27.0-27.5 m b.s. This species also shows many specimens killed by predatory gastropods. Corbula gibba is found in the sublittoral zone out to a depth of $250 \mathrm{~m}$. At Skagen its first occurrence is at 74.89-75.00 $\mathrm{m}$, in the early Subboreal, but it becomes common in the Subatlantic and occurs in high numbers only in the last part of the Subatlantic from the 30 m level, often bored.

Finally, two single finds of Saxicavella jeffreys $i$ and Pholas dactylus occurred at the 20.0-20.5 m level. Saxicavella jeffreysi is in recent Danish waters not very abundant at depths between 25 and $50 \mathrm{~m}$, while Pholas dactylus would only be expected to be found at depths less than $10 \mathrm{~m}$. Pholas dactylus is a boring form found in hard substrates, which is far from the actual sediment occurring at this level in the Skagen Well. The fragmentary Pholas dactylus can be regarded as one of the allochthonous elements that can be seen in connection with the accessory finds mentioned in Appendix 3 and commented upon below.

Among the accessory finds the barnacles and sea urchins dominate. Also fish remains are found, often in the form of vertebrae, but an otolith appears as well. Other fossil remains are serpulids, bryozoans, crustaceans, and plant and insect remains, which taken as a whole very well characterise the near-shore environment. On the other hand, no concretions are found like the ones from the Younger Yoldia Sea, or pyrite as found at the base of the Holocene and the Eemian. Although these accessory elements cannot be quanti- 
fied, they offer some additional information when considered together with the sedimentological and mollusc records.

\section{Conclusive remarks on the Skagen Well}

In the description given above, the faunal record is the basis for understanding the climatic changes in the Skagen Well, supplemented by the observation on the changes in the sediments. However, the changes found during the Holocene are most likely to be connected with changes in facies, and here the changing depth is the most prominent agent, ending up with the last event represented by the depositional history of the Skagen Spit.

Based on the dating of the Holocene and the Late Weichselian, the descriptions have been given in terms of episodes. Especially the Holocene strata points to a development from deeper- to shallow-water facies from Preboreal to Subatlantic. In this development there appears to be a facies change that can be compared to the bottom communities as known from the Skagerrak-Kattegat region when going from the deeper-water communities of the present day, the so-called Maldane-Ophiura sarsi community, to the Venus community of the more shallow seas.

The mollusc assemblages in the Skagen sequence indicate a deeper-water facies during the Eemian, the Weichselian and the older Holocene in contrast to what hitherto was known in other parts of the Danish area during the Late Quaternary.

The Skagen Well has a record of the changing seas during the Late Quaternary, from the Eemian through the Weichselian (although only in parts) and the Holocene. For the first time within the Danish area, the full record of the marine environmental transition from the Late Pleistocene to the Holocene can be demonstrated on the basis of molluscs. However, not all the episodes known from the Skagen Well can be found in marine facies of the other regions, but thanks to the new records from the North Sea around the Jydske Rev area, a near to full Holocene marine record is at hand, including part of the Preboreal (Petersen 1998).

\section{The environmental changes through time in the seven sectors based on the molluscan records}

The recorded mollusc species within each area are given in Appendix 6. Regarding the environmental changes through time within the Danish realm, the seven sectors will be considered from the Eemian, starting in the south within the classical area where Forchhammer named the deposits the Cyprina clay.

\section{Eemian species sorted after climatic affinities}

\section{The Bælt Sea}

\author{
Age: Eemian \\ Climatic regions: asbl \\ Class Bivalvia \\ Subclass Heterodonta
}

\author{
Order Myoida \\ Mya truncata Linnaeus 1758 \\ Total for climatic regions asb. : 1 (1.7\%) \\ Climatic regions: .sb. \\ Class Bivalvia \\ Subclass Heterodonta \\ Order Veneroida \\ Arctica islandica (Linnaeus 1767) \\ Order Myoida \\ Zirfaea crispata (Linnaeus 1758) \\ Total for climatic regions .sb. : 2 (3.4\%) \\ Climatic regions: .sbl \\ Class Bivalvia \\ Subclass Pteriomorpha \\ Order Mytiloida \\ Mytilus edulis Linnaeus 1758 \\ Order Pterioida
}

